\title{
KLASIFIKASI LEVEL NON-PROLIFERATIF RETINOPATI DIABETIK DENGAN ENSEMBLE CONVOLUTIONAL NEURAL NETWORK
}

\author{
Ruvita Faurina ${ }^{1}$, Endina Putri Purwandari ${ }^{2}$, Mario Tiara Pratama ${ }^{3}$, Indra Agustian ${ }^{4}$ \\ 1,2 Teknik Informatika, Universitas Bengkulu, Jl. W.R Supratman Kandang Limun, Bengkulu, Indonesia \\ ${ }^{3,4}$ Teknik Elektro, Universitas Bengkulu, Jl. W.R Supratman Kandang Limun, Bengkulu, Indonesia

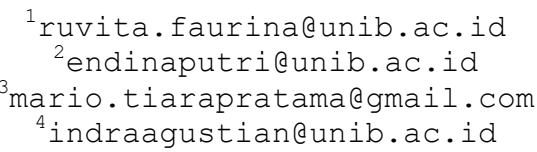

Abstrak: Penelitian ini mengusulkan penggunaan algoritme CNN ensemble classifier untuk klasifikasi level non-proliferatif Retinopati diabetik. Penelitian ini membandingkan metode transfer learning feature-extraction dan fine-tuning untuk memilih yang terbaik untuk digunakan. Pada lapisan klasifikasi, dibandingkan penggunaan lapisan GAP dan Flatten dengan menggunakan metode dropout, mode terbaik digunakan sebagai mode final klasifikasi. Arsitektur yang digunakan adalah DenseNet201, InceptionV3 dan MobileNetV2, Masing-masing model diuji dengan optimasi SGD dan ADAM. Keputusan prediksi diambil berdasarkan metode average voting. Hasil pengujian masing-masing arsitektur menunjukkan hasil terbaik adalah fine tuning, GAP, dan optimasi ADAM. Model final fine-tuning DenseNet201, InceptionV3 dan MobileNetV2 dapat mengklasifikasi level retinopati diabetik dengan akurasi pada data uji masing-masing 93\%, 94\% dan 89\%. Sedangkan performa klasifikasi model ensemble untuk keseluruhan kelas memiliki akurasi terendah 95,6\% dan F1-Score terendah 91,3\%.

Kata Kunci: retinopati diabetik, deep learning, convolutional neural network, ensemble classifier, DenseNet201, InceptionV3, MobileNetV2.

\begin{abstract}
This research proposes the use of deep learning algorithm CNN ensemble classifier for the classification of non-proliferative diabetic retinopathy. This study compares transfer learning feature-extraction and fine-tuning methods to select the best one to use. The classification layer is compared using the GAP and Flatten layers with the dropout method, the best layer will be used in the classification system. The architecture used is DenseNet201, InceptionV3, and MobileNetV2. Each model is tested with SGD and ADAM optimization. The final prediction is decided by the average voting method. The test results for each architecture show that the best results are fine-tuning, GAP, and $A D A M$ optimization. The final fine-tuning models DenseNet201, InceptionV3, and MobileNetV2 were able to classify the rate of diabetic retinopathy on the test data with accuracy at 93\%, 94\%, and 89\%, respectively. Meanwhile, the performance of the ensemble model classification for the entire class has the lowest accuracy of $95.6 \%$ and the lowest F1Score of $91.3 \%$.
\end{abstract}

Keywords: diabetic retinopathy, deep learning, convolutional neural network, ensemble classifier, DensNet, InceptionV3, MobileNetV2.

\section{Pendahuluan}

Diabetic Retinopathy atau retinopati diabetic (RD) adalah komplikasi dari penyakit diabetes yang memicu terjadinya penyumbatan pembuluh darah pada daerah retina mata, dan dapat menyebabkan kebutaan. RD disebut sebagai penyebab utama kebutaan pada usia produktif di negara Barat [1]. Riset Kesehatan Dasar (Riskesdes) 2013 menemukan 6,9\% penduduk Indonesia yang berusia di atas 15 tahun menderita DM dan Rumah Sakit Cipto Mangunkusumo mencatat persentase komplikasi kedua terbesar setelah neuropati adalah retinopati [2].

Metode konvensional yang digunakan untuk mendiagnosa level retinopati diabetik adalah 
Jurnal Pseudocode, Volume VIII Nomor 1, Februari 2021, ISSN 2355-5920, e-ISSN 2655-1845 www.ejournal.unib.ac.id/index.php/pseudocode

dengan melakukan pemeriksaan langsung ke dalam bola mata pasien oleh dokter ahli dengan menggunakan oftalmoskop atau melalui pengamatan terhadap hasil rekaman citra digital dari kamera fundus [3]. Pemeriksaan manual oleh dokter dapat memakan waktu dan hasil pemeriksaan tergantung pada tingkat keahlian dokter yang melakukan pemeriksaan. Kesalahan diagnosa pada pasien RD beresiko memperparah komplikasi. Data penelitian menyebutkan bahwa 90\% dari meningkatnya keparahan RD dapat dicegah dengan pemeriksaan dan perawatan pada pasien yang tepat [4]. Oleh karena itu, diperlukan sebuah sistem yang dapat mendiagnosis level retinopati diabetik secara tepat dan cepat serta dengan biaya yang murah dan juga dapat digunakan untuk deteksi awal yang dapat menggantikan ketidakhadiran dokter atau pakar.

Banyak penelitian yang telah dilakukan untuk membuat model sistem deteksi otomatis level keparahan RD. Metode yang banyak dilakukan sebelumnya adalah dengan melakukan ekstraksi fitur atau informasi yang berhubungan dengan level RD pada citra fundus [5], fitur atau informasi tersebut dimasukan ke algoritme klasifikasi tertentu seperti random forest[6], support vector machine[7], dan AdaBoost classifier[8].

Berbeda dengan algoritme klasifikasi yang memerlukan ekstraksi fitur di awal, Convolutional Neural Network (CNN) merupakan sebuah teknik deep learning yang dapat melakukan ekstraksi fitur pada data citra, dengan model deep learning, umumnya $\mathrm{CNN}$ lebih baik dalam merepresentasikan data citra [9]-[11]. Proses pelatihan model CNN membutuhkan data pelatihan yang besar, umumnya antara puluhan ribu hingga jutaan data. Memaksakan melakukan pelatihan model $\mathrm{CNN}$ dengan layer yang dalam dengan data yang kecil akan menghasilkan sistem klasifikasi yang tidak maksimal. Sementara itu, data citra fundus yang tersedia masih terbatas. Solusi dari masalah tersebut dengan metode transfer learning yang memungkinkan untuk melakukan pelatihan model deep learning dengan memanfaatkan bobot awal model pre-train yang sudah ada [12].

Penelitian ini mengusulkan pendekatan ensemble classifier dari tiga arsitektur $\mathrm{CNN}$, yaitu arsitektur DensNet, InceptionV3 dan MobileNetV2 dengan pengambilan keputusan prediksi berdasarkan metode average voting. Pemilihan arsitektur berdasarkan penelitian[13] yang mereview performa berbagai jenis arsitektur CNN untuk klasifikasi retinopati diabetik.

\section{PEnElitian TERKait}

Model komputasi untuk klasifikasi level RD sebenarnya telah sejak lama dikembangkan oleh para peneliti, bahkan sebelum berkembangnya algoritme convolutional neural network. Para peneliti terdahulu umumnya melakukan rekayasa tingkat keabuan piksel pada suatu Gambar untuk mengekstraksi fitur atau informasi yang berhubungan dengan level RD pada Gambar fundus. Fitur yang telah di ekstraksi tersebut kemudian dimasukan ke algoritme klasifikasi tertentu seperti random forest, support vector machine, dan AdaBoost classifier. Metode ini dinilai masih kurang efektif, dan tingkat akurasi yang tidak konsisten, karena sifat dari ekstraksi ciri yang sangat dipengaruhi oleh kualitas warna dan kontras Gambar.

Convolutional Neural Network secara implisit memungkinkan melakukan ekstraksi fitur dan klasifikasi, yang sekaligus menjawab kesulitan dalam pembuatan model klasifikasi level RD. 
Jurnal Pseudocode, Volume VIII Nomor 1, Februari 2021, ISSN 2355-5920, e-ISSN 2655-1845 www.ejournal.unib.ac.id/index.php/pseudocode

Secara umum pekerjaan dalam bidang ini yang memanfaatkan jaringan Convolutional neural network terbagi menjadi kelompok klasifikasi biner dan klasifikasi multi kelas.

Pada kelompok klasifikasi biner, penelitian [14] merancang model convolutional neural network untuk mendeteksi citra fundus dengan RD. Mereka menggunakan dataset pribadi yang terdiri dari 800 data pelatihan dan 200 data validasi dalam penelitian tersebut. Hasil evaluasi model mereka menunjukan $94.5 \%$ dari data validasi dapat diprediksi dengan benar yang juga menunjukan bahwa model mereka lebih unggul dari model komputasi tradisional. Penelitian [15] mengusulkan model jaringan $\mathrm{CNN}$ untuk mendeteksi RD. Model tersebut dilatih dengan open dataset kaggle dan divalidasi dengan data DiaretdB1. Berdasarkan klasifikasi biner yang mereka lakukan, model tersebut menghasilkan sensitivitas $93.6 \%$.

Sementara, pada klasifikasi multi kelas, penelitian [16] mengusulkan rancangan model convolutional neural network untuk mendeteksi dan mengklasifikasi level keparahan RD. Penelitian ini menggunakan 78.000 Gambar sebagai data pelatihan dan 5000 Gambar sebagai data validasi yang diambil dari open dataset Kaggle. Hasil evaluasi model ini menghasilkan akurasi $75 \%$ pada data validasi. Penelitian [17] mengajukan model CNN dengan memodifikasi arsitektur Xception. Penelitian ini menggunakan dataset dari kompetisi Kaggle APTOS 2019. Hasil pengujian menunjukan model usulan mereka menghasilkan akurasi $83.09 \%$ dan lebih unggul dibandingkan dengan model dengan model dengan arsitektur ResNet59, MobileNet, InceptionV3 dan Xception original. [17] mengajukan pendekatan transfer learning sebagai solusi dalam mengatasi keterbatasan dan ketidak seimbangan data kaggle yang mereka gunakan pada saat pelatihan jaringan CNN. Hasil pengujian mereka menunjukan jaringan dengan arsitektur Inception ResNet V2 menghasilkan skor kappa paling tinggi 0.76 .

\section{MetodologI}

Dataset awal dari penelitian ini terdiri dari 1460 citra fundus yang dipilih secara acak dari data APTOS competition 2019[18]. Masingmasing kelas memiliki 365 data. Label data telah disediakan oleh APTOS dalam format csv. Dari data ini jumlah data pada masing-masing level RD tidak seimbang, sehingga dilakukan augmentasi data untuk menyeimbangkannya. Augmentasi yang dilakukan juga memperbesar dataset dan memvariasikan citra baru berdasarkan citra dataset awal. Augmentasi pra-pelatihan terdiri dari cropping (memotong citra menjadi beberapa bagian), shearing (menggeser sisi citra sehingga citra membentuk jajaran genjang). Sedangkan augmentasi pada saat proses pelatihan terdiri dari rotasi, flip horizontal dan flip vertikal.

Sebelum masuk ke tahapan ensemble, citra fundus terlebih dahulu dilakukan pra-proses normalisasi kontras dengan metode Contrast Limited Adaptive Histogram Equalization (CLAHE)[19] dan dilanjutkan dengan konversi ke grayscale dan Gaussian Blur[20]. Citra fundus dari dataset, dikumpulkan dari kamera fundus yang berbeda, sehingga memiliki tingkat kontras yang berbeda, CLAHE berfungsi untuk menyeragamkan tingkat kontras citra fundus tersebut. Gaussian blur berfungsi untuk mereduksi noise pada citra fundus. Keluaran Gaussian blur merupakan input ensemble CNN.

Model ensemble yang diusulkan terdiri dari tiga model yaitu DensNet201, InceptionV3 dan 
Jurnal Pseudocode, Volume VIII Nomor 1, Februari 2021, ISSN 2355-5920, e-ISSN 2655-1845 www.ejournal.unib.ac.id/index.php/pseudocode

MobileNetV2. Output masing-masing model feature map, penggunaan GAP dimaksudkan untuk berupa probabilitas level $\mathrm{RD}$, kemudian mereduksi jumlah parameter yang akan masuk ke diputuskan berupa probabilitas level RD, jaringan neural network yang berguna untuk kemudian diputuskan prediksi akhir dengan meminimalkan resiko overfitting.

menggunakan metode average voting. Blok Vektor yang dihasilkan oleh GAP akan masuk diagram sistem ditunjukkan pada Gambar 1.

ke hidden layer jaringan neural network. Pada

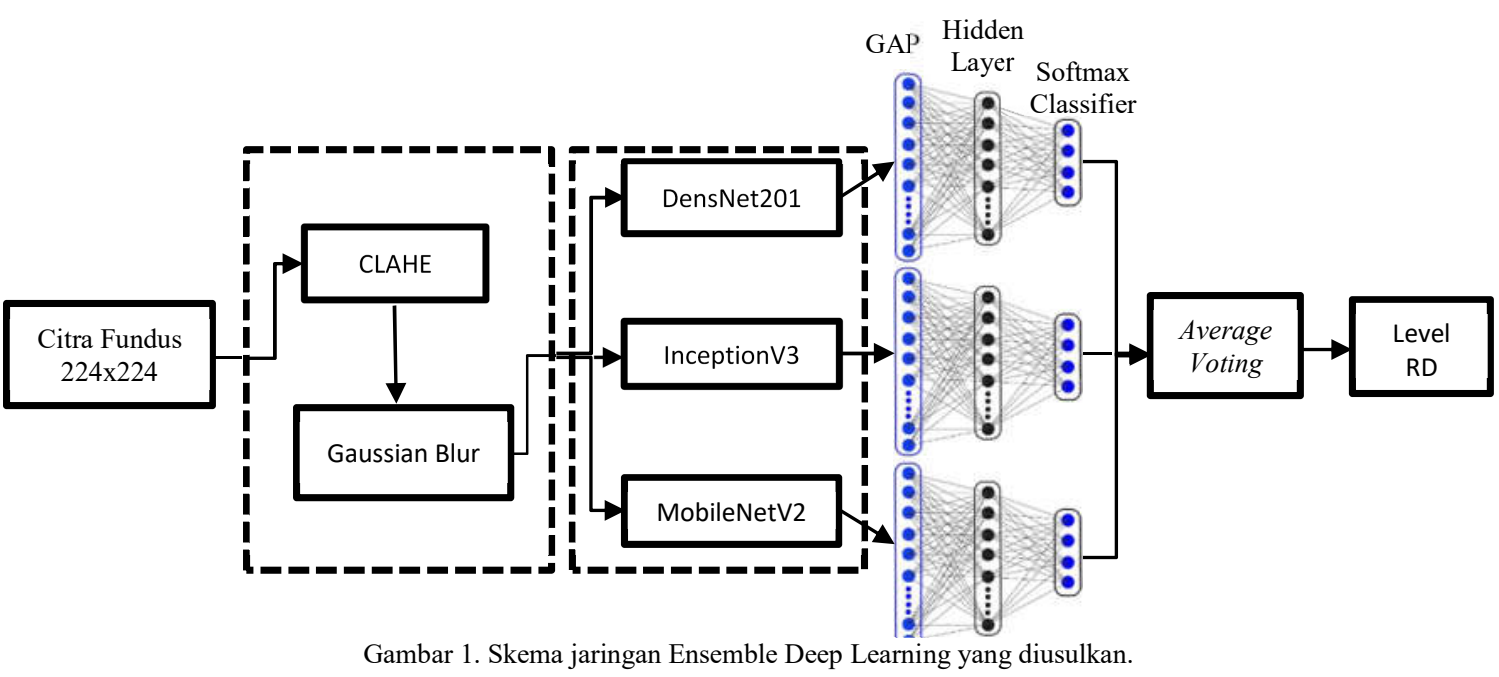

Penggunaan tiga arsitektur pada model ensemble convolutional neural network bertujuan agar model dapat mengekstraksi fitur RD yang lebih beragam pada Gambar fundus. Ensemble convolutional neural network ini terdiri dari 2 jaringan utama yaitu jaringan konvolusi dan jaringan neural network.

Jaringan konvolusi atau convolutional layer merupakan kumpulan sejumlah filter yang pada dasarnya merupakan matriks dengan ukuran dan pola tertentu yang disebut juga dengan bobot. Setiap filter dikalikan dengan matriks Gambar untuk menghasilkan fitur yang berguna pada proses klasifikasi oleh jaringan neural network.

Sebelum masuk ke jaringan neural network, feature map yang dihasilkan oleh jaringan konvolusi yang masih dalam dimensi matriks ( $h x$ $w x d)$ akan diubah menjadi dimensi vektor ( $1 x 1 x$ d) oleh lapisan Global Average Pooling (GAP). Selain berfungsi untuk mengubah format data

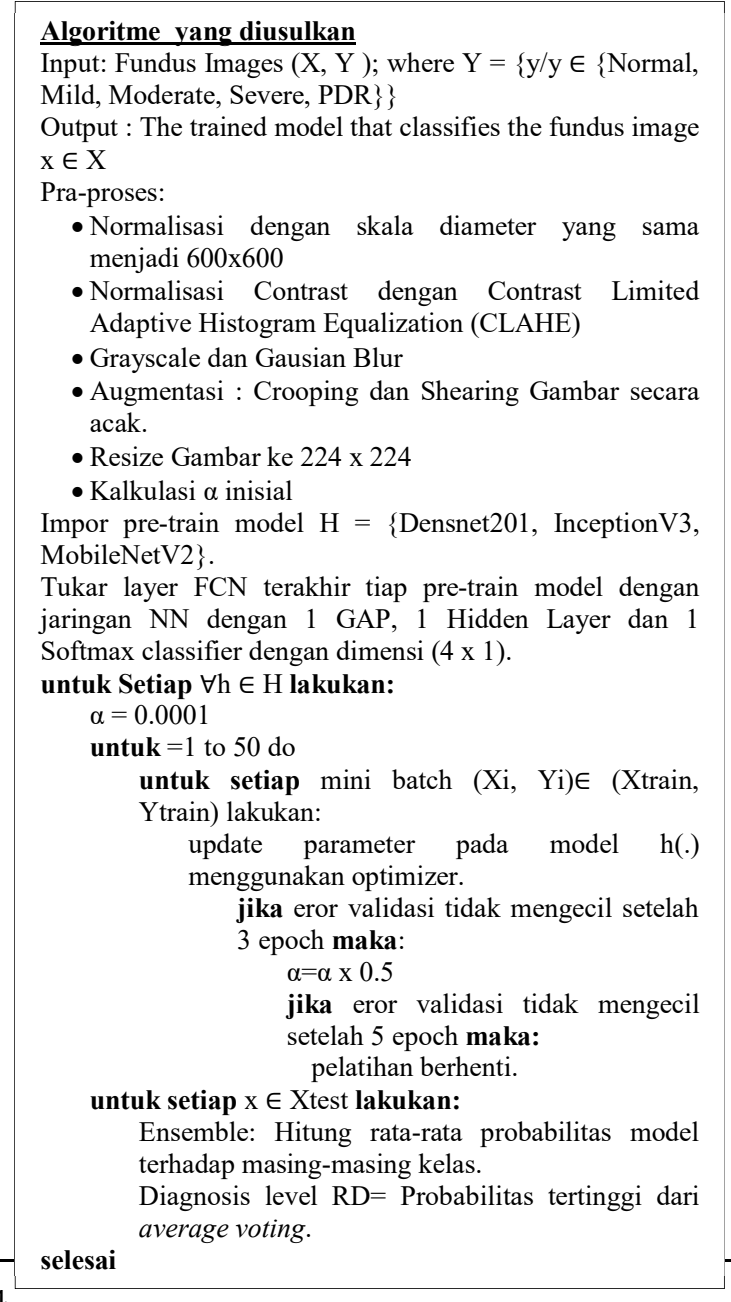


Jurnal Pseudocode, Volume VIII Nomor 1, Februari 2021, ISSN 2355-5920, e-ISSN 2655-1845 www.ejournal.unib.ac.id/index.php/pseudocode

lapisan neural network, sebelum dan setelah hidden layer disisipkan fungsi dropout yang bertujuan untuk mendeaktivasi neuron pada jaringan neural network secara acak berdasarkan bobot pada masing-masing neuron selama proses pelatihan. Pada lapisan terakhir jaringan neural network, dipasang fungsi softmax yang bertugas untuk menghitung probabilitas masing-masing neuron terhadap masing-masing kelas (level RD).

Penggunaan layer average voting mewakili proses ensemble pada penelitian ini. Probabilitas dari 3 fungsi softmax yang dimiliki oleh masingmasing model convolutional neural network akan diambil nilai probabilitas rata-rata. Nilai tersebutlah yang akan menjadi probabilitas kelas klasifikasi level RD.

\section{Metode Pelatihan}

Proses pelatihan pada penelitian ini menggunakan metode transfer learning[22]. Transfer learning pada penelitian ini menggunakan pendekatan feature extraction dan Fine-tuning. Pada tahapan pelatihan feature extraction, pembaharuan bobot hanya dilakukan pada jaringan neural network sementara jaringan konvolusi menggunakan bobot dari ImageNet. Selanjutnya, pada pendekatan Fine-tuning semua jaringan akan dilatih. Bobot awal model adalah bobot dari pelatihan feature extraction. Pengujian dilakukan terhadap beberapa variasi jumlah neuron dan dropout, hingga menemukan variasi jumlah neuron dan rasio terbaik pada masing-masing model.

Learning rate merupakan hyperparameter yang berpengaruh untuk terciptanya model optimal pada proses pelatihan jaringan convolutional neural network yang berbasis backpropagation. Penelitian ini melakukan tuning learning rate model pada optimizer SGD[23] dan Adam[24]. Variasi nilai learning dan jenis optimizer dengan akurasi tertinggi dan loss paling minimum akan diambil sebagai model optimal dan akan digunakan pada ensemble model.

\section{Metode Pengujian}

Model pada penelitian ini dievaluasi dengan menghitung akurasi model terhadap keseluruhan data uji dengan menggunakan confusion matrix [21]. Selanjutnya, evaluasi lanjutkan dilakukan dengan menghitung tingkat Accuracy, precision, recall dan fl-score untuk tiap kelas (level RD), masing-masing dihitung dengan menggunakan persamaan (1)(2)(3) dan (4).

Accuracy $=\frac{T P+T N}{T P+F P+T N+F N}$

Precision $=\frac{T P}{T P+F P}$

$\operatorname{Recall}(R)=\frac{T P}{T P+F N}$

$F 1=\frac{2 R P}{R+P}$

\section{HASIL DAN PEMBAHASAN}

Total dataset setelah augmentasi pra-pelatihan yang digunakan pada penelitian ini adalah 8000 citra fundus ukuran $224 \times 224$ piksel $^{2}$, dibagi menjadi 6000 citra untuk pelatihan, 1500 untuk validasi dan 500 untuk pengujian. Distribusi dataset dan level RD ditunjukkan pada Tabel 1 . Citra fundus hasil setelah dinormalisasi ukuran, dilanjutkan dengan normalisasi kontras dan Gaussian blur, seperti ditunjukkan pada Gambar 2.

Tabel 1. Distribusi dataset

\begin{tabular}{cccc}
\hline \hline Level RD & Pelatihan & Validasi & Testing \\
\hline 0-Normal & 1500 & 375 & 125 \\
1-Mild & 1500 & 375 & 125 \\
2-Moderate & 1500 & 375 & 125 \\
3-Severe & 1500 & 375 & 125 \\
Jumlah & $\mathbf{6 0 0 0}$ & $\mathbf{1 5 0 0}$ & $\mathbf{5 0 0}$ \\
\hline \hline
\end{tabular}

Penelitian ini menggunakan dua model transfer learning yang diujikan, yang pertama adalah model ekstraksi fitur dan yang kedua adalah model fine- 
Jurnal Pseudocode, Volume VIII Nomor 1, Februari 2021, ISSN 2355-5920, e-ISSN 2655-1845

www.ejournal.unib.ac.id/index.php/pseudocode

tuning. Pada model pertama, model jaringan pretrain hanya berfungsi sebagai ekstraktor fitur, tidak ada modifikasi atau update bobot pada model pretrain, output pre-train model dimasukkan ke dalam jaringan klasifikasi dengan mode dropout regulation. Pada model kedua, dilakukan perbaikan bobot pada jaringan konvolusi model pre-train dan mengganti lapisan terakhir dengan jaringan klasifikasi dengan dropout regulation.

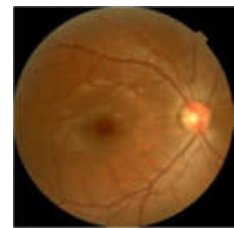

Input

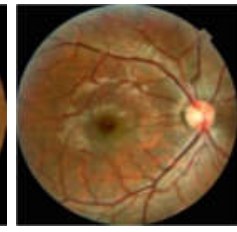

CLAHE

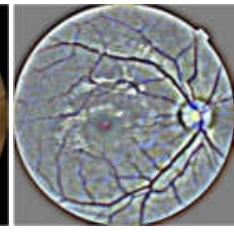

Gaussian Blur
Gambar 2. Pra-proses olah dataset citra fundus

Pada tahap transfer learning mode ekstraksi fitur, pada lapisan klasifikasi layer pertama dilakukan pengujian dua jenis layer yaitu, Global Average Pooling(GAP) dan Flatten, dengan jumlah neuron 2048; 1024; 512; 256 dan 128 serta rasio dropout $0.5 ; 0.25$ dan 0.15 . Pada arsitektur Densnet201, lapisan GAP memiliki kinerja yang lebih baik dibanding flatten. Akurasi terbaik model DensNet201 adalah $73 \%$ pada pelatihan dan $69 \%$ pada validasi dengan struktur dua hidden layer dengan 512 neuron dan rasio dropout 0.25 . GAP dapat meminimalkan overfitting pada model, hal ini terlihat pada kecilnya selisih antara akurasi pelatihan dan akurasi validasi. Pada arsitektur InceptionV3, lapisan GAP juga memiliki kinerja yang lebih baik dengan akurasi terbaik pada pelatihan $56 \%$ dan validasi $58 \%$ dengan struktur 2 hidden layer dengan 256 neuron dan rasio dropout 0.15. pada arsitektur MobileNetV2, GAP juga menunjukkan kinerja yang lebih baik dengan akurasi terbaik pada pelatihan $64 \%$ dan validasi
$61 \%$ dengan struktur 2 hidden layer dengan 1024 neuron dan rasio dropout 0.25 .

Berdasarkan hasil uji pada tahap pertama, dipilih lapisan GAP sebagai lapisan pertama jaringan klasifikasi untuk tahap pengujian transfer learning mode fine-tuning. Pada tahap fine-tuning Jumlah neuron yang digunakan adalah 2048; 1024; 512; 256 dan 128 serta rasio dropout $0.5 ; 0.25$ dan 0.15. Hasil pengujian pada arsitektur Densnet201 menunjukkan kinerja terbaik dengan hidden layer yang memiliki 512 neuron dengan rasio dropout 0.15 dalam mengklasifikasi level RD, akurasi validasi yang mencapai $80 \%$ dan loss yang rendah 0.48. Dengan fungsi early stopping, karena akurasi model sudah tidak mengalami peningkatan signifikan dari epoch ke 19, proses pelatihan berhenti pada epoch ke 24 dari target 100 epoch. Fine-tuning pada arsitektur InceptionV3 memberikan hasil terbaik dengan satu hidden layer yang memiliki 1024 neuron dengan rasio dropout 0.25 , hal ini terlihat pada akurasi validasi yang mencapai $81 \%$ dan loss 0.44 arsitektur InceptionV3 terhenti oleh early stopping pada epoch 25. Kurva konvergensi pelatihan InceptionV3 menunjukan model sudah cukup konvergen yang ditandai dengan eror minimal yang sudah stabil. Sedangkan pada arsitektur MobileNetV2, hasil terbaik dengan satu hidden layer yang memiliki 512 neuron dengan rasio dropout 0.5 . Akurasi terbaik model ini adalah 0.74 \% dengan loss 0.7. MobileNetV2 terhenti oleh early stopping pada epoch 18. Akurasi validasi model masih di bawah $80 \%$.

Berdasarkan hasil pengujian tahap kedua, tahapan selanjutnya adalah optimasi learning rate. Dari tahap kedua diperoleh jumlah neuron dan rasio dropout optimal untuk masing-masing model. Proses optimasi learning rate dilakukan 
Jurnal Pseudocode, Volume VIII Nomor 1, Februari 2021, ISSN 2355-5920, e-ISSN 2655-1845 www.ejournal.unib.ac.id/index.php/pseudocode

untuk memperbaiki akurasi dan konvergensi model. Metode optimasi yang diuji pada penelitian ini adalah, Stochastic Gradient Descent(SGD) dan Adaptive Moment Estimation(Adam). Optimasi learning rate, dilakukan dengan dua pendekatan, pertama dengan memberikan nilai learning rate tetap selama proses pelatihan, dengan variasi learning rate $0.1 ; 0.01 ; 0.001 ; 0.0001 ; 0.00001$. Pendekatan kedua dengan metode automatic reduce learning rate, dengan cara memberikan nilai learning rate awal sebesar 0.0001 kemudian sistem akan memperkecil nilai learning rates sebesar learning rate dikalikan $0.5\left(\alpha_{\text {baru }}=\alpha-0,5\right.$. $\alpha$ jika akurasi validasi model tidak membaik setelah 3 epoch.

Tabel 2. Optimasi Learning-rate

\begin{tabular}{|c|c|c|c|c|}
\hline \multirow{3}{*}{ Optimizer } & \multirow{2}{*}{$(\alpha)$} & \multicolumn{3}{|c|}{ Akurasi (0 s/d 1) } \\
\cline { 3 - 5 } & & D201 & MV2 & InV3 \\
\hline \multirow{5}{*}{ SGD } & 0.1 & 0.72 & 0.66 & 0.81 \\
\cline { 2 - 5 } & 0.01 & 0.83 & 0.79 & 0.89 \\
\cline { 2 - 5 } & 0.001 & 0.87 & 0.75 & 0.87 \\
\cline { 2 - 5 } & 0.0001 & 0.8 & 0.77 & 0.79 \\
\cline { 2 - 5 } & 0.00001 & 0.79 & 0.74 & 0.5 \\
\cline { 2 - 5 } & Auto * & 0.8 & 0.75 & 0.76 \\
\hline \multirow{5}{*}{ Adam } & 0.1 & 0.25 & 0.24 & 0.42 \\
\cline { 2 - 5 } & 0.01 & 0.46 & 0.59 & 0.47 \\
\cline { 2 - 5 } & 0.001 & 0.68 & 0.74 & 0.81 \\
\cline { 2 - 5 } & 0.0001 & 0.85 & 0.85 & 0.92 \\
\cline { 2 - 5 } & 0.00001 & 0.92 & 0.81 & 0.89 \\
\cline { 2 - 5 } & Auto * & $\mathbf{0 . 9 4}$ & $\mathbf{0 . 9 0}$ & $\mathbf{0 . 9 3}$ \\
\hline
\end{tabular}

D201: DensNet201, MV2: MobileNetV2, InV3: InceptionV3 SGD *: DensNet201 = 2.5e-5; MobileNetV2=2.5e-5; Inception $\mathrm{V} 3=5 \mathrm{e}-5$.

Adam *: DensNet201 = 1.25-5; MobileNetV2=2.5e-5; InceptionV $3=1.25 \mathrm{e}-5$

Tabel 2 menunjukkan hasil pengujian optimasi, akurasi terbaik model dengan arsitektur DensNet201 adalah $94 \%$ dengan learning rate $1.125 \mathrm{e}-5$ menggunakan Adam optimizer, akurasi terbaik arsitektur InceptionV3 93\% dengan learning rate $1.25 \mathrm{e}-5$ dengan Adam optimizer sementara akurasi terbaik MobileNetV2 saat learning rate 2.5e-5 dengan Adam optimizer adalah 90\%. Kualitas model juga diperlihatkan dengan kurva konvergensi hasil pelatihan masingmasing arsitektur pada Gambar 3, 4 dan 5. Kurva

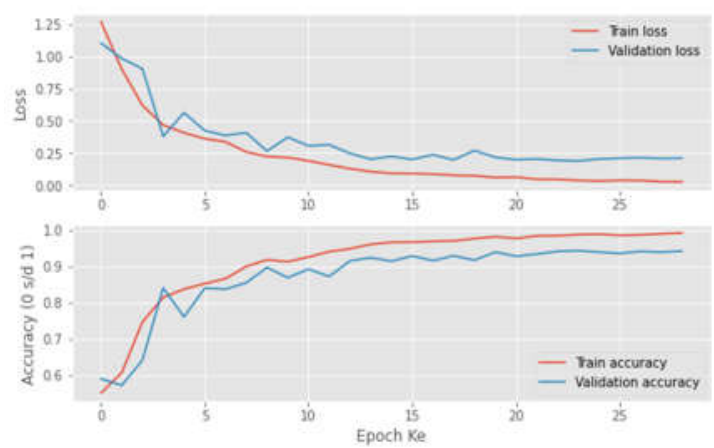

Gambar 3. Kurva konvergensi pelatihan DensNet201

konvergensi mengindikasikan bahwa masingmasing model sudah berhasil konvergen ke titik error minimal. Akurasi validasi model juga telah konvergen dan stabil. Sehingga model tersebut dijadikan sebagai model optimal yang kemudian akan dijadikan basis model pada algoritme Ensemble yang diusulkan.

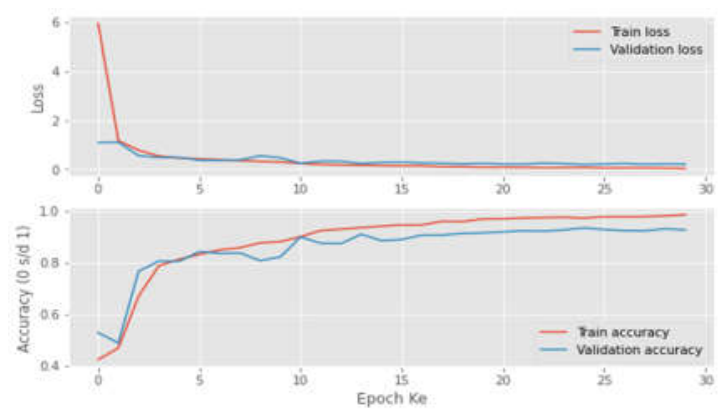

Gambar 4. Kurva konvergensi pelatihan InceptionV3

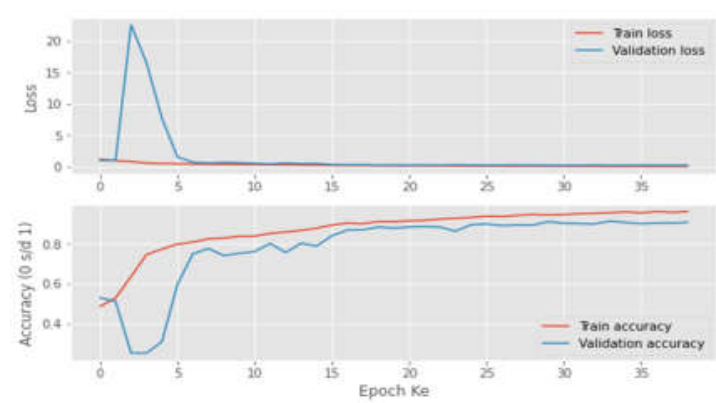

Gambar 5. Kurva konvergensi pelatihan MobileNetV2

Total 500 data citra fundus diujikan, diperoleh Confusion matrix dari model ensemble pada Gambar 6. Pada klasifikasi multi-kelas, 
Jurnal Pseudocode, Volume VIII Nomor 1, Februari 2021, ISSN 2355-5920, e-ISSN 2655-1845 www.ejournal.unib.ac.id/index.php/pseudocode

keberhasilan klasifikasi sesuai aktual adalah True Positive dan True Negative sebagai keberhasilan klasifikasi untuk data bukan kelas aktual, baik prediksi pada kelas yang lain benar atau salah, diperoleh rekapitulasi parameter-parameter confusion matrix untuk mengukur performa model pada masing-masing kelas ditunjukkan pada Tabel 3. Dengan menggunakan indikator pada persamaan (1)-(4) diperoleh data kinerja untuk kelas 0(Normal),1(Mild), 2(Moderate), dan 3(Severe) pada Tabel 4

TP adalah True Positive, yaitu jumlah data positif yang diklasifikasi dengan benar oleh sistem. TN adalah True Negative, yaitu jumlah data negatif yang diklasifikasi dengan benar oleh sistem. FN adalah False Negative, yaitu jumlah data negatif namun diklasifikasi salah oleh sistem. FP adalah False Positive, yaitu jumlah data positif namun diklasifikasi salah oleh sistem.

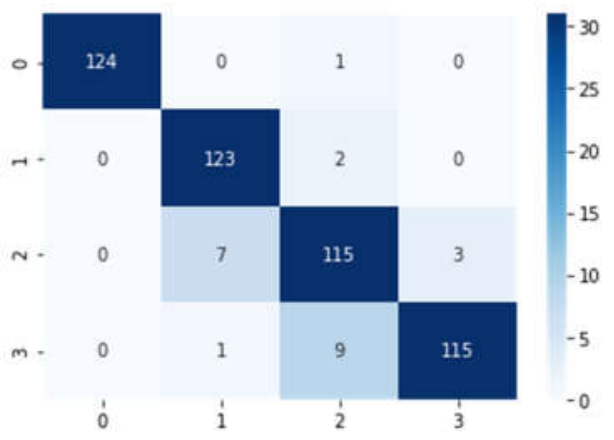

Gambar 6. Confusion Matrix final model ensemble

Tabel 3. Total parameter Confusion Matrix

\begin{tabular}{|c|r|r|r|r|}
\hline Kelas & \multicolumn{1}{|c|}{ TP } & \multicolumn{1}{|c|}{ TN } & \multicolumn{1}{|c|}{ FP } & \multicolumn{1}{|c|}{ FN } \\
\hline 0 & 124 & 375 & 0 & 1 \\
\hline 1 & 123 & 367 & 8 & 2 \\
\hline 2 & 115 & 363 & 12 & 10 \\
\hline 3 & 115 & 372 & 3 & 10 \\
\hline
\end{tabular}

Tabel 4. Parameter performa model ensemble

\begin{tabular}{|c|r|r|r|r|}
\hline Kelas & Accuracy & Precision & Recall & F1 \\
\hline 0 & 0,998 & 1,000 & 0,992 & 0,996 \\
\hline 1 & 0,980 & 0,939 & 0,984 & 0,961 \\
\hline 2 & 0,956 & 0,906 & 0,920 & 0,913 \\
\hline 3 & 0,974 & 0,975 & 0,920 & 0,947 \\
\hline
\end{tabular}

Berdasarkan Tabel 4, performa model memprediksi kelas untuk aktual kelas sesungguhnya memiliki akurasi di atas 95\%, ratarata $97,7 \%$, dengan catatan bahwa kesalahan prediksi ke kelas lain adalah True Negative. Performa Precision diatas 90\%, rata-rata 95,5\% mengindikasikan rasio prediksi data positif terhadap jumlah data positif ditambah data negatif yang terdeteksi positif. Performa Recall di atas $92 \%$, rata-rata $95,54 \%$, mengindikasikan rasio prediksi data positif terhadap data positif ditambah data positif terdeteksi negatif. F1-Score yang merupakan rata-rata harmonik dari precision dan recall, di atas 91\%, dengan rata-rata 95,4\%. F1-Score mengindikasikan bahwa model memiliki precision dan recall yang baik.

\section{KESIMPULAN}

Pada penelitian ini diusulkan algoritme ensemble CNN untuk klasifikasi Retinopati Diabetik Non-proliferative dengan pra-proses CLAHE dan Gaussian Blur, transfer learning finetuning arsitektur DensNet, InceptionV3 dan MobileNetV32, lapisan klasifikasi terdiri dari GAP, dropout hidden layer dan softmax classifier, dan dioptimasi menggunakan algoritme ADAM. Model final fine-tuning DensNet, InceptionV3 dan MobileNetV32 dapat mengklasifikasi level retinopati diabetik dengan akurasi pada data uji masing-masing 93\%, 94\% dan 89\%. Sedangkan performa klasifikasi model ensemble untuk masing-masing kelas memiliki akurasi terendah 95,6\% dan F1-Score terendah 91.3\%. Untuk penelitian selanjutnya model ensemble yang diusulkan perlu diuji untuk dataset baru. 
Jurnal Pseudocode, Volume VIII Nomor 1, Februari 2021, ISSN 2355-5920, e-ISSN 2655-1845 www.ejournal.unib.ac.id/index.php/pseudocode

\section{UCAPAN TERIMA KASIH}

Tim Peneliti mengucapkan terima kasih kepada Unversitas Bengkulu yang telah memberikan hibah melalui skema Penelitian Unggulan Fakultas di Fakultas Teknik Universitas Bengkulu Tahun Anggaran 2020 dengan Nomor Kontrak: 2098 /UN30.13/HK/2020.

\section{REFERENSI}

[1] Erlvira and E. E. Suryawijaya, "Retinopati Diabetes," Cermin Dunia Kedokt., vol. 46, no. 3, pp. 220-224, 2019.

[2] Kementerian Kesehatan RI, "WASPADA DIABETES, Eat well Live well," Pusat Data dan Informasi, 2014

[3] M. S. Sari, Ratna, Rasmala Dewi, "Pola Retinopati Diabetik Pada Pasien Diabetes Mellitus Rawat Jalan Di RSUD Raden Mattaher Jambi,” J. Healthc. Technol. Med., vol. 5, no. 2, pp. 287-296, 2019.

[4] P. Z. Z. Tapp, Robyn J., Jonathan E. Shaw, C. Alex Harper, Maximilian P. De Courten, Beverley Balkau, Daniel J. McCarty, Hugh R. Taylor, Timothy A. Welborn, "The prevalence of and factors associated with diabetic retinopathy in the Australian population," Diabetes Care, vol. 26, no. 6, pp. 1731-1737, 2003.

[5] Z. Gao, J. Li, J. Guo, Y. Chen, Z. Yi, and J. Zhong, "Diagnosis of Diabetic Retinopathy Using Deep Neural Networks," IEEE Access, vol. 7, pp. 3360-3370, 2019.

[6] R. Casanova, S. Saldana, E. Y. Chew, R. P. Danis, C. M. Greven, and W. T. Ambrosius, "Application of random forests methods to diabetic retinopathy classification analyses," PLoS One, vol. 9, no. 6, pp. 1-8, 2014.

[7] M. Faisal, D. Wahono, I. K. E. Purnama, M. Hariadi, and M. H. Purnomo, "Classification of diabetic retinopathy patients using support vector machines (SVM) based on digital retinal image," J. Theor. Appl. Inf. Technol., vol. 59, no. 1, pp. 197-204, 2014.

[8] A. Dhakal and S. Shakya, "Detection and Classification of Diabetic Retinopathy using Adaptive Boosting and Artificial Neural Network," no. August, 2019.

[9] A. Krizhevsky, I. Sutskever, and G. E. Hinton, "ImageNet classification with deep convolutional neural networks," Adv. Neural Inf. Process. Syst., vol. 2, pp. 1097-1105, 2012.

[10] Y. Lecun, Y. Bengio, and G. Hinton, "Deep learning," Nature, vol. 521, no. 7553, pp. 436-444, 2015.
[11] Y. Bengio, A. Courvile, and P. Vincent, "Representation Learning: A Review and New Perspectives," IEEE Trans. Pattern Anal. Mach. Intell., vol. 35, no. 8, pp. 17981828, 2013

[12] H. C. Shin et al., "Deep Convolutional Neural Networks for Computer-Aided Detection: CNN Architectures, Dataset Characteristics and Transfer Learning," IEEE Trans. Med. Imaging, vol. 35, no. 5, pp. 1285-1298, 2016.

[13] I. Kandel and M. Castelli, "Transfer learning with convolutional neural networks for diabetic retinopathy image classification. A review," Appl. Sci., vol. 10, no. 6, 2020.

[14] Xu K, Feng D, Mi H. Deep convolutional neural network-based early automated detection of diabetic retinopathy using fundus image. Molecules. 2017 Dec;22(12):2054.

[15] W. M. Gondal, J. M. Köhler, R. Grzeszick, G. A. Fink, and M. Hirsch, "Weakly-supervised localization of diabetic retinopathy lesions in retinal fundus images," in Proc. IEEE Int. Conf. Image Process. (ICIP), Sep. 2017, pp. 2069-2073

[16] H. Pratt, F. Coenen, D. M. Broadbent, S. P. Harding, and Y. Zheng, "Convolutional neural networks for diabetic retinopathy," Procedia Comput. Sci., vol. 90, pp. 200205, Jan. 2016

[17] Krishnan AS, Bhat V, Ramteke PB, Koolagudi SG. " $A$ Transfer Learning Approach for Diabetic Retinopathy Classification Using Deep Convolutional Neural Networks". In2018 15th IEEE India Council International Conference (INDICON) 2018 Dec 16 (pp. 1-6). IEEE.

[18] "APTOS", 2019, [online] Available: https://www.kaggle.com/c/aptos2019-blindnessdetection/overview/aptos-2019

[19] Pizer SM, Amburn EP, Austin JD, Cromartie R, Geselowitz A, Greer T, ter Haar Romeny B, Zimmerman $\mathrm{JB}$, Zuiderveld K. "Adaptive histogram equalization and its variations". Computer vision, graphics, and image processing. 1987 Sep 1;39(3):355-68.

[20] Haddad RA, Akansu AN. "A class of fast Gaussian binomial filters for speech and image processing". IEEE Transactions on Signal Processing. 1991 Mar 1;39(3):723-7.

[21] Townsend JT. "Theoretical analysis of an alphabetic confusion matrix”. Perception \& Psychophysics. 1971 Jan 1;9(1):40-50. 
Jurnal Pseudocode, Volume VIII Nomor 1, Februari 2021, ISSN 2355-5920, e-ISSN 2655-1845 www.ejournal.unib.ac.id/index.php/pseudocode

[22] Shin HC, Roth HR, Gao M, Lu L, Xu Z, Nogues I, Yao J, Mollura D, Summers RM. "Deep convolutional neural networks for computer-aided detection: CNN architectures, dataset characteristics and transfer learning”. IEEE transactions on medical imaging. 2016 Feb 11;35(5):1285-98
[23] Bottou L. "Stochastic gradient descent tricks". InNeural networks: Tricks of the trade 2012 (pp. 421-436). Springer, Berlin, Heidelberg.

[24] Zhang Z. "Improved adam optimizer for deep neural networks". In 2018 IEEE/ACM 26th International Symposium on Quality of Service (IWQoS) 2018 Jun 4 (pp. 1-2). IEEE 